\title{
Alternative rock music in Yugoslavia in the period between 1980-1991 and its influence on the present music cultures in Macedonia, Serbia and Croatia
}

\author{
PhD defense on the $17^{\text {th }}$ of September 2012.
}

Awarding institution: Institute of Art Studies, Bulgarian Academy of Sciences, Sofia

\section{Julijana Zhabeva Papazova}

Affililija Nikolovski-Luj (State Music and Ballet School), Skopje jzabeva@yahoo.com

Addressing alternative rock music in the territory covered by Yugoslavia (in terms of consumption, production, exchange and network connections between music and cultural organizations, groups, organizers and journalists), the research for the doctoral thesis is based on the critical analysis of musical communication, music recordings and a selection of musical scenes.

The main aim of the dissertation is to research the reconstruction of alternative rock music in the Socialist Federal Republic of Yugoslavia (SFRY) in the period between the early eighties to 1991, a historical period after which the republics gradually fell apart. The next goal of the dissertation is to outline and trace the contribution of alternative rock music to the development of music in general and the cultural life in the Yugoslavian republics in the period after the collapse of the SFRY and of the Federal Republic of Yugoslavia which came to an end in 2003.

The research process ranges from a general theoretical approach, associated with musical communication; musical analysis, related to the relationship between recorded music and live performance; and analysis of the music scenes, tracking the sociocultural aspects and interdisciplinarity as part of the methodology. Overall, the survey provides, for the first time, new academic knowledge related to alternative rock in Yugoslavia, in particular in terms of a chronology of Yugoslav alternative rock and the analysis of local alternative rock music styles.

The research is framed within debates regarding alternative rock history and theoretical aspects that are predominantly of Anglo-American origin, such as: Fonarow (2006); Gracyk (2001); Jones (2008); Moore (2010); Ramet (ed, 1994); Taylor (2006); Thompson (2000); and Wicke (1995). In addition, modest but significant research literature published in former Yugoslavia relates to the main subject namely: biographical monographs on alternative rock bands and musicians (Žikić, 1999; Rigonat, Milosavljević and Kostić 2011), Janjatović's encyclopedia of Yugoslav rock (2001) and Monroe's (2005) PhD research on Yugoslavian avant-garde bands and artists Laibach and NSK. 
The thesis first defines alternative rock and its ideology through a short history of this genre in both the Western and non-Western world. This is further explored through a socio-cultural history of Yugoslav alternative rock in terms of its development and the relationship between rock music and society, politics and culture.

The analysis is then refined through a focus on five Yugoslav alternative rock bands: Šarlo Akrobata from Belgrade, Laibach from Trbovlje, Mizar from Skopje, Grč from Rijeka and SCH from Sarajevo. This, then, provides the background for an assessment of the influence of the pre-1991 Yugoslav alternative rock in the period after 1991 in the activities of a selection of post-Yugoslavian bands, magazines, festivals and record labels.

The research is mainly based on qualitative methods used by ethnology and anthropology of music, including participant observation, biographical approach, interviews, inductive method and music notation analysis using the composition and notation programs Cubase and Sibelius. Main sources for the study were festivals and concerts (both live and recorded), albums from the period 1980-1991, video documentaries, music journalistic publications such as Džuboks (“Jukebox") and Rock and other publications by and about alternative rock bands. This is complemented by fieldwork in the capitals of the previously Yugoslavian republics: Skopje, Belgrade, Ljubljana and Zagreb.

The research presents, for the first time, a chronology of the history of Yugoslav alternative rock during the eighties. The knowledge of such historical development is the foundation for further new research. In the process, the thesis also covers an overview of publications devoted to the study of alternative rock. Also for the first time, music scenes of alternative rock bands in Yugoslavia during the eighties are described local (Republican) and translocal music scenes (communications between the Republics), as well as ex-Yugoslavian local, translocal and virtual music scenes.

Finally, study of the impact of the Yugoslav alternative rock within parts of the former Yugoslavia after 1991 is based on a combination of the analysis of bands, publishers and concerts with a summary treatment of these on two levels: the first concerns the Internet and virtual communication and the second relates to the continuation of musical contacts and collaborations between groups of the now former Yugoslavia. There the influence of alternative rock music on the development of music in general and cultural life can be noticed in the consumption, production and connections within network exchanges based in various cultural centres (mostly the cities of Skopje, Belgrade, Novi Sad, Zagreb and Rijeka) such as music and cultural organizations, music bands, artistic groups, organizers and journalists.

\section{References}

Fonarow, W. (2006) Empire of Dirt. The Aesthetics and Rituals of British Indie Music. Middletown, Connecticut: Wesleyan University Press

Gracyk, T. (2001) J Wanna Be Me: Rock Music and the Politics of Identity. Philadelphia: Temple University Press

Janjatović, P. (2001) Ilustrovana Yu Rock Enciklopedija 1960-2000. Novi Sad: Prometej

Jones, W. C. (2008) The Rock Canon. Canonical Values in the Reception of Rock Albums. Hampshire: Ashgate Publishing Company

Monroe, A. (2005) Interrogation Machine: Laibach and NSK. Cambridge, MA: The MIT Press

Moore, R. (2010) Sells Like Teen Spirit: Music Youth Culture and Social Crisis. New York and London: New York University Press 
Ramet, P. S. Ed. (1994) Rocking the State: Rock Music and Politics in Eastern Europe and Russia. Boulder, San Francisco, Oxford: Westview Press

Rigonat, F., Milosavljević, A., Kostić Z-C. (2011) Partibrejkers. Srce kuca tu je. Beograd: LOM

Taylor, S. (2006) The A to $X$ of Alternative Music. London: Continuum

Thompson, D. (2000) Alternative Rock. San Francisco: Miller Freeman Books

Wicke, P. (1995) Rock Music: Culture, Aesthetics and Sociology. Cambridge:

Cambridge University Press

Žikić, A. (1999) Mesto u međavi (priča o Milanu Maldenoviću) Novi Sad: Matica Srpska. 